\title{
A Rare Case of Oral Myiasis Caused by Phormia regina (Meigen) (Diptera: Calliphoridae) in an Intubated Patient
}

\author{
Entübe Hastada Phormia regina (Meigen) (Diptera: Calliphoridae) \\ Nedenli Nadir Bir Oral Miyazis Olgusu

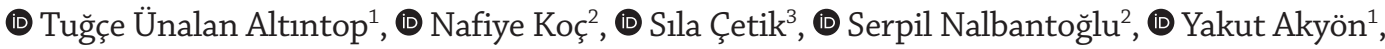 \\ (1) Sibel Ergüven ${ }^{1}$ \\ ${ }^{1}$ Hacettepe University Faculty of Medicine, Department of Medical Microbiology, Ankara, Turkey \\ ${ }^{2}$ Ankara University Faculty of Veterinary Medicine, Department of Parasitology, Ankara, Turkey \\ ${ }^{3}$ Hacettepe University Faculty of Medicine, Department of Internal Medicine, Ankara, Turkey
}

Cite this article as: Ünalan Altıntop T, Koç N, Çetik S, Nalbantoğlu S, Akyön Y, Ergüven S. A Rare Case of Oral Myiasis Caused

by Phormia regina (Meigen) (Diptera: Calliphoridae) in an Intubated Patient. Turkiye Parazitol Derg 2022;46(1):75-77.

\begin{abstract}
Myiasis is the infestation of tissues with living larvae. Oral myiasis is an extremely rare form of the disease, with open mouth, unconsciousness, and poor oral hygiene being the predisposing factors. It is generally observed in the tropics or subtropics, as well as rural places with low socio-economic income. Mechanical removal and ivermectin are frequently used as treatments. Herein, we present a case of oral myiasis in a 69-year-old male intubated patient with myocardial infarction. Multiple larvae were observed in the mouth and mechanically removed. With the microscopic investigation, the larvae were identified as Phormia regina (Meigen) (Diptera: Calliphoridae), which is extremely rare globally. For preventing oral myiasis, good patient care, good sanitary practice for oral health, efficient treatment of dental diseases, and fly population control, usage of masks for the risk groups are recommended. Keywords: Myiasis, oral, Phormia regina, intubation, larvae
\end{abstract}

ÖZ

Miyazis, canlı larvaların doku infestasyonuna verilen isimdir. Oral miyazis hastalığın oldukça nadir görülen formudur. Predispozan faktörler açık ağız, bilinç kaybı ve kötü ağız hijyenidir. Genellikle tropik ve subtropik bölgelerde ve düşük sosyo-ekonomik seviyeli kırsal kesimlerde görülmektedir. Tedavi için mekanik temizleme ve ivermektin kullanımı tercih edilmektedir. Burada, 69 yaşında entübe bir miyokard infarktüsü hastasında oral miyazis olgusu sunulacaktır. Hastanın ağzında çok sayıda larva tespit edilmiş ve mekanik olarak temizlenmiştir. Mikroskopik inceleme sonucu larvalar oldukça nadir bir tür olan Phormia regina (Meigen) (Diptera: Calliphoridae) olarak tespit edilmiştir. Oral miyazisin önlenmesinde, hasta bakımı, ağız sağlı̆̆ı bakımı, diş hastalıklarının etkin tedavisi, sinek popülasyon kontrolü ve riskli gruplarda maske kullanımı önerilmektedir.

Anahtar Kelimeler: Miyazis, oral, Phormia regina, entübasyon, larva

\section{INTRODUCTION}

Myiasis is the infestation of tissues by living dipterous insect larvae meaning fly (muia) and disease (iasis). It is oftenly seen in tropical and subtropical areas, since larvae causing myiasis favor the warm and humid conditions. It generally invades vertebrates but human infestations are rare but reported, since humans are the accidental hosts (1). Myiasis is a destructive disease, which requires early diagnosis and intervention.
Oral myiasis is a rare manifestation of the disease since the oral cavity is not an appropriate body part for egg-laying. The predisposing factors can be local or systemic; local factors include incompetent lips, poor oral hygiene, halitosis, dental diseases, nocturnal mouth breathing, facial trauma, ulcer like lesions and oral carcinoma (2). Systemic factors can be summarized as cognitive difficulties, dementia, cerebral palsy, diabetes, alcohol consumption and poor hygiene (3).

Received/Geliş Tarihi: 16.05.2021 Accepted/Kabul Tarihi: 17.12.2021

Address for Correspondence/Yazar Adresi: Tuğçe Ünalan Altıntop, Hacettepe University Faculty of Medicine, Department of Medical Microbiology, Ankara, Turkey

Phone/Tel: +90 5375740037 E-mail/E-Posta: t.unalan91@gmail.com ORCID ID: orcid.org/0000-0001-5318-2942 
Phormia regina species are the less common causes of human myiasis among the blowflies (Calliphoridae). These species are known to be attracted to malodorous suppurating wounds and especially used in forensic medicine to indicate the postmortem interval (4). Here we report an oral myiasis case in a 69-year-old, male, intubated patient with myocardial infarction and cognitive impairment.

\section{CASE REPORT}

A 69-year-old male patient who had granulomatosis with polyangiitis since 2012 was admitted to the hospital with complaints of coughing, fatigue and swelling of the feet. The patient was from low socio-economic background and residing in a rural area of Turkey. He had nodular lesions in both lungs and chronic renal failure (Stage V). There was no evidence of an upper respiratory tract involvement though he had poor oral hygiene. During his follow-up, the patient developed dyspnea and chest pain. The arterial blood gas analysis at room air was as follows: $\mathrm{pH}$ : 6.9, $\mathrm{pO}_{2}: 80 \mathrm{mmHg}, \mathrm{pCO}_{2}: 26 \mathrm{mmHg}, \mathrm{HCO}_{3}: 4.1$ $\mathrm{mEq} / \mathrm{L}$ and lactate: $12.2 \mathrm{mEq} / \mathrm{L}$. The patient was then intubated and mechanical ventilation was started. Further investigations revealed highly elevated cardiac markers and thus, he was diagnosed with non-ST elevation myocardial infarction. Ten days after hospitalization and one day after intubation, multiple larvae were seen crawling in patient's oral cavity. The larvae were initially mechanically removed and then the oral cavity was flushed with $3 \%$ saline. Some of the larvae were delivered to the parasitology laboratory for classification.

Two larvae were sent to Ankara University Veterinary Faculty, Parasitology Laboratory. The size was investigated with stereomicroscope Zeiss (Stemi 2000-C). It was dissected under stereomicroscope and a slide is prepared with canada balsam. With the microscopic investigation of cephalopharyngeal skeleton and posterior peritreme under stereo-microscope Leica (S8AP0), it was identified as Phormia regina (Meigen) (Diptera: Calliphoridae) Phase 2 and 3 (5-8) (Figure 1, 2). Since it was brought within saline solution, adult forms could not be obtained.

Then the patient was consulted to the department of otorhinolaryngology for further management. Fiber optic and detailed physical investigations were performed but no more

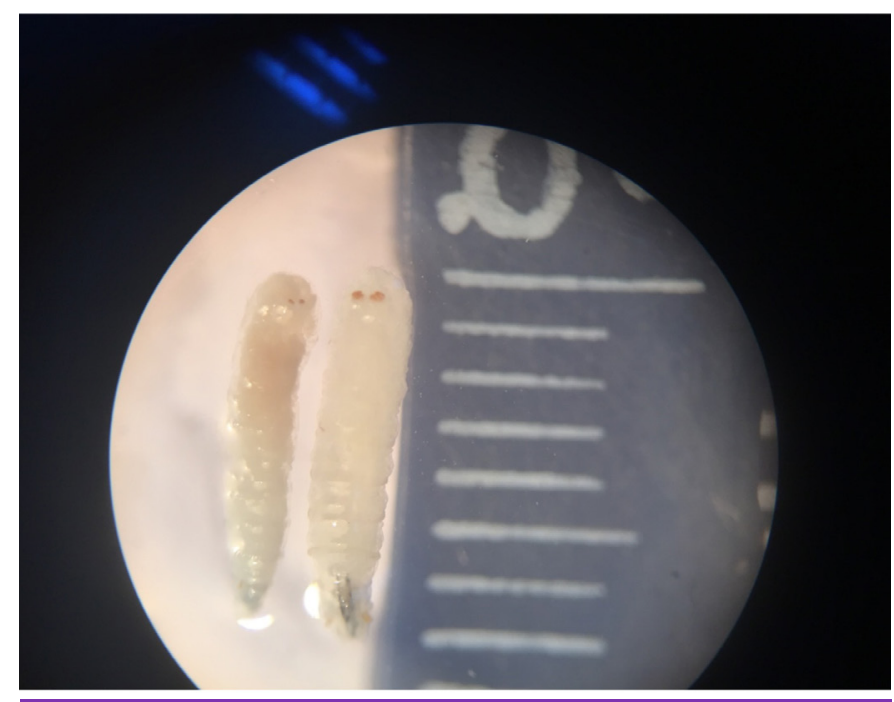

Figure 1. The size of the larvae larvae were detected in the oral cavity, nose or ear. Larvae did not appear again in the follow-up.

\section{DISCUSSION}

Oral myiasis an uncommon manifestation of the disease and generally requires certain predisposing factors as poor oral hygiene and factors causing an open mouth, and neurological deficits. In our case the patient is intubated and unconscious. He was coming from a rural area of Turkey with a warm and humid weather where many farms are located which can attract various endemic insects and parasites. In addition, social vulnerability and poor sanitary conditions are common in rural areas of Turkey. A number of oral myiasis cases were reported in Turkey. A nineyear-old boy who is intubated because of pneumoniae, and who has poor oral hygiene was infested by Lucilia sericata (9). Two cases of Sarcophaga spp. were reported; an 82-year-old woman with oral squamous cell carcinoma (10) and a 15-year-old male patient with tuberculosis meningitis (11). Two children one healthy and one with chronic periodontitis were infested by Wohlfahrtia magnifica $(12,13)$. Two reports of Diptera: Calliphoridae family defined an intubated unconscious patient and a farmer with poor oral hygiene $(14,15)$. Arslan et al. (16) also reported a gingival myiasis of a 2-year-old boy with dental caries and poor oral hygiene. Hypoderma bovis larvae were removed in a child's oral cavity with poor oral hygiene (17).

Phormia regina species are uncommon cause of myiasis, which is known to cause a facultative disease especially infestations on necrotic dermal lesions (18). Two cases of oral myiasis in hospitalized patients were reported from Iran (19). The first report was made in 1975 from Quebec in a patient with traumatic dermal myiasis (20). Others were wound myiasis (21-24), ulcers of chronic psoriasis (25), and necrotic scalp myiasis (26).

Myiasis is treated by mechanical evacuation with clinical forceps or surgical debridement; ivermectin which results in the palsy and death of the parasites (27), phenol, turpentine oil, chloroform or nitrofurazone spray $(27,28)$. Prevention is based on applying fly population control strategies, practicing good sanitary care. The

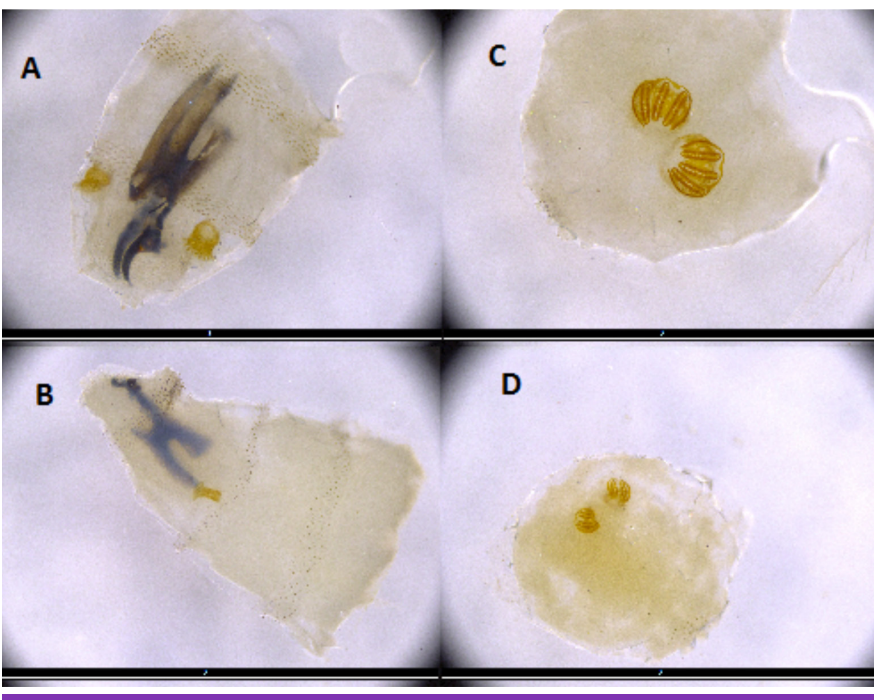

Figure 2. A) Cephalopharyngeal skeleton of $2^{\text {nd }}$ instar larvae. B) Cephalophrayngeal skeleton and anterior peritreme of $3^{\text {rd }}$ instar larvae. C, D) Posterior peritreme of $2^{\text {nd }}$ and $3^{\text {rd }}$ instar larvae 
avoidance of oral myiasis includes good oral hygiene, efficient treatment of dental diseases and usage of masks in patients with lip incompetence (28).

Information: This case report was presented as a poster at $10^{\text {th }}$ Balkan Congress of Microbiology (16-18 November 2017 Sofia, Bulgaria).

\section{*Ethics}

Informed Consent: The informed consent was obtained from the patient.

Peer-review: Externally and internally peer-reviewed.

\section{* Authorship Contributions}

Surgical and Medical Practices: S.Ç., Data Collection or Processing: T.Ü.A., N.K., S.N., Y.A., S.E., Analysis or Interpretation: T.Ü.A., N.K., S.N., Y.A., S.E., Literature Search: T.Ü.A., Y.A., S.E., Writing: T.Ü.A., N.K., S.Ç., S.N., Y.A., S.E.

Conflict of Interest: No conflict of interest was declared by the authors.

Financial Disclosure: The authors declared that this study received no financial support.

\section{REFERENCES}

1. Droma EB, Wilamowski A, Schnur H, Yarom N, Scheuer E, Schwartz E. Oral myiasis: a case report and literature review. Oral Surg Oral Med Oral Pathol Oral Radiol Endod 2007; 103: 92-6.

2. Reddy MH, Das N, Vivekananda MR. Oral myiasis in children. Contemp Clin Dent 2012; 3(Suppl 1): S19-22.

3. Rana AK, Sharma R, Sharma VK, Mehrotra A, Singh R. Otorhinolaryngological myiasis: the problem and its presentations in the weak and forgotten. Ghana Med J 2020; 54: 173-8.

4. Eldridge BF, Edman JD. Medical entomology: a textbook on public health and veterinary problems caused by arthropods: Springer Science \& Business Media; 2012.

5. Dinçer Ş. İnsan ve Hayvanlarda Myiasis. In: Parazitoloji'de Artropod Hastalıkları ve Vektörler. Özcel MA, Daldal N, editors. Türkiye Parazitoloji Derneği Yayın No: 13, Ege Üniv. Basımevi, İzmir; 1997.p.169-234.

6. Pekmezci D, Pekmezci GZ, Açici M, Gökalp G, Tütüncü M. A case of auricular, anal and umbilical myiasis caused by the larvae of Phormia regina (Meigen)(Diptera: Calliphoridae) in neonatal kittens. Turkiye Parazitol Derg 2014; 38: 71.

7. Szpila K. Key for the identification of third instars of European blowflies (Diptera: Calliphoridae) of forensic importance. Current concepts in forensic entomology: Springer; 2009. p. 43-56.

8. Zumpt F. Myiasis in man and animals in the Old World. A textbook for physicians, veterinarians and zoologists. Myiasis in Man and Animals in the Old World A Textbook for Physicians, Veterinarians and Zoologists, 1965.

9. Laçin N, Yalçın M. A Rare Case of Oral Myiasis Caused by Lucilia sericata in an Intubated Patient from Southeast Turkey. Turkiye Parazitol Derg 2021; 45: 326-8.
10. Yücesan B, Babür C, Koç N, Kulıç S. Gingival Myiasis on Oral Squamous Cell Carcinoma in Turkey: A Case Report. Turkiye Parazitol Derg 2021; 45: 160-3.

11. Yazar S, Dik B, Yalçin S, Demirtaş F, Yaman O, Oztürk M, Sahin I. Nosocomial Oral Myiasis by Sarcophaga sp. in Turkey. Yonsei Med J 2005; 46: 431-4.

12. Çetın Özdemır E, Ekşi F, Şenyurt SZ, Üstün K, Karaoğlan İ, Ercıyas K. Wohlfahrtia magnifica'dan kaynaklanan gingival miyaz olgusu [A case of gingival myiasis caused by Wohlfahrtia magnifica]. Mikrobiyol Bul 2014; 48: 512-7.

13. Büyükkurt MC, Miloğlu Ö, Nalbantoğlu S, Uslu H, Yolcu U, Aktaş O. Oral Myiasis in A Child Due to Wohlfahrtia Magnifica: Original Image. Turkiye Klinikleri J Med Sci 2008; 28: 782-5.

14. Taş Cengiz Z, Yılmaz H, Beyhan YE, Yakan Ü, Ekici A. An Oral Myiasis Case Caused by Diptera (Calliphoridae) Larvae in Turkey. Turkiye Parazitol Derg 2019; 43: 213-5.

15. Gursel M, Aldemir OS, Ozgur Z, Ataoglu T. A rare case of gingival myiasis caused by diptera (Calliphoridae). J Clin Periodontol 2002; 29: 777-80.

16. Arslan S, Islamoğlu A, Çobanoğlu B. A rare case of gingival myiasis in a 2-year-old child. Int J Paediatr Dent 2013; 23: 387-8.

17. Erol B, Unlü G, Balci K, Tanrikulu R. Oral myiasis caused by hypoderma bovis larvae in a child: a case report. J Oral Sci 2000; 42: 247-9.

18. Prevention CfDCa. Laboratory Identification of Parasites of Public Health Concern. December 14, 2017.

19. Vazirianzadeh B, Rahdar M, Maraghi S. Phormia regina (Diptera, Cyclorrhapha: Calliphoridae): myiasis agent, status and principals of prevention in Khoozestan sw Iran. J ExpZool, India 2008; 11: 473-6.

20. Ali-Khan FE, Ali-Khan Z. A case of traumatic dermal myiasis in Quebec caused by Phormia regina (Meigen) (Diptera: Calliphoridae). Can J Zool 1975; 53: 1472-6.

21. Vinay K, Handa S, Khurana S, Agrawal S, De D. Dermatoscopy in Diagnosis of Cutaneous Myiasis Arising in Pemphigus Vulgaris Lesions. Indian J Dermatol 2017; 62: 440.

22. Seaquist ER, Henry TR, Cheong E, Theologides A. Phormia regina myiasis in a malignant wound. Minn Med 1983; 66: 409-10.

23. Miller KB, Hribar LJ, Sanders LJ. Human myiasis caused by Phormia regina in Pennsylvania. J Am Podiatr Med Assoc 1990; 80: 600-2.

24. Abdel-Hafeez EH, Mohamed RM, Belal US, Atiya AM, Takamoto M, Aosai F. Human wound myiasis caused by Phormia regina and Sarcophaga haemorrhoidalis in Minia Governorate, Egypt. Parasitol Res 2015; 114: 3703-9.

25. Hall RD, Anderson PC, Clark DP. A case of human myiasis caused by Phormia regina (Diptera: Calliphoridae) in Missouri, USA. J Med Entomol 1986; 23: 578-9.

26. Alexis JB, Mittleman RE. An unusual case of Phormia regina myiasis of the scalp. Am J Clin Pathol 1988; 90: 734-7.

27. Hassona Y, Scully C, Aguida M, de Almeida OP. Flies and the mouth. J Investig Clin Dent 2014; 5: 98-103.

28. Shinohara EH, Martini MZ, de Oliveira Neto HG, Takahashi A. Oral myiasis treated with ivermectin: case report. Braz Dent J 2004; 15: 79-81. 